\title{
Pathogenicity and aggressiveness of Macrophomina phaseolina isolates to castor (Ricinus communis)
}

\author{
Monaliza R. Claudino ${ }^{1}$ \& Dartanha J. Soares ${ }^{1,2}$ \\ ${ }^{1}$ Universidade Estadual da Paraíba, Cx. Postal 131, 74001-970, Campina Grande, PB, Brazil; ${ }^{2}$ Embrapa Algodão, Cx. Postal 174, \\ 58428-095, Campina Grande, PB, Brazil
}

Author for correspondence: Dartanha J. Soares. e-mail: dartanha.soares@embrapa.br

\begin{abstract}
Charcoal rot, caused by Macrophomina phaseolina, is one of the most important diseases of castor (Ricinus communis) in the growing regions of Northeastern Brazil, particularly in the State of Bahia, which concentrates $65 \%$ of the country's production. The pathogenicity and aggressiveness of the charcoal rot pathogen was assessed in twenty-seven isolates of M. phaseolina obtained from six plant species: Ricinus communis $(\mathrm{n}=21)$, Gossypium hirsutum $(\mathrm{n}=2)$, Sesamum indicum $(\mathrm{n}=1)$, Helianthus annuus $(\mathrm{n}=1)$, Jatropha gossypifolia $(\mathrm{n}=1)$ and Arachis hypogaea $(\mathrm{n}=1)$. All isolates were pathogenic and exhibited a range of aggressiveness towards BRS Energia cultivar regardless of their host of origin.
\end{abstract}

Key words: charcoal rot, sclerotial wilt, variability.

Charcoal rot is one of the most important diseases of castor (Ricinus communis L.) in the state of Bahia, the main region of castor production in Brazil, which accounts for $65 \%$ of the country's production (Severino et al. 2012). Nevertheless, there is no information on yield losses due to charcoal rot on castor in Brazil. Macrophomina phaseolina (Tassi) Goid., the fungus causing charcoal rot infects more than 500 plant species, including some of the world's most important crops such as soybean, cotton and corn ( $\mathrm{Su}$ et al. 2001; Gupta et al. 2012). In Brazil, charcoal rot is common and it is considered one of the most prevalent disease problems of soybean (Reis et al. 2014).

The fungal infection and disease development are favored by high temperatures and drought (Dhingra and Sinclair 1978; Grezes-Besset et al. 1996; Gupta et al. 2012) and in Northeastern Brazil, castor is usually cultivated under such conditions (Severino et al. 2012). Moreover, castor is frequently cultivated in association or in rotation with crops that are also susceptible to M. phaseolina, such as cowpea, corn and cotton, allowing the maintainance of high populations of the fungus in the soil.

Recent initiatives to incorporate castor in the crop rotation system in areas of the Brazilian Cerrado, mainly after soybean (Evogene, 2011, 2013), can further increase the importance of this pathogen in those areas. Therefore, this study had the objective of assessing the pathogenicity and aggressiveness of M. phaseolina isolates obtained from different hosts and locations to castor.

Twenty-seven isolates of $M$. phaseolina were obtained from plants of castor (Ricinus communis, $\mathrm{n}=21$ ), sesame (Sesamum indicum, $\mathrm{n}=1$ ), sunflower (Helianthus annuus, $\mathrm{n}=1$ ), bellyache bush (Jatropha gossypifolia, $\mathrm{n}=1$ ), cotton (Gossypium hirsutum, $\mathrm{n}=2$ ) and peanut (Arachis hypogaea $\mathrm{n}=1$ ), showing typical symptoms of charcoal rot, collected in the states of Bahia (BA), Maranhão (MA), Paraíba (PB) and Rio Grande do Norte (RN) (Table 1).

The inoculum production and inoculation technique were adapted from Mihail (1992), Grezes-Besset et al. (1996), and Amusa et al. (2007). Parboiled rice grains (100 g) and water $(20 \mathrm{~mL})$ were added to $200 \mathrm{~mL}$ Erlenmeyer flasks and autoclaved at $120^{\circ} \mathrm{C}$ for $30 \mathrm{~min}$. After cooling, five mycelial plugs of each M. phaseolina isolate, obtained from 5-day-old cultures grown on potato-dextrose-agar (PDA) were placed in the flasks, which were then maintained at $30{ }^{\circ} \mathrm{C}$, in continuous dark, until complete colonization of the rice grains. The flasks were shaken daily to allow a fast and even colonization. After 15 to 20 days, when full colonization was reached, the colonized rice grains were dried overnight in a laminar flow cabinet and then stored in paper bags at room temperature until inoculation.

Castor seeds of BRS Energia were treated with carboxin+thiram (Coutinho et al., 2012) and sown in $280 \mathrm{~mL}$ nursery tubes filled with an autoclaved substrate consisting of peat and vermiculite ( $3: 1 \mathrm{v}: \mathrm{v})$. Inoculation was performed by inserting a colonized rice grain into the stem of each 30-dayold castor plant $2 \mathrm{~cm}$ above the soil surface. The stems were previously wounded with a metal rod in order to facilitate the insertion of the rice grain. Plants having non-colonized rice grains inserted in the stems as described above were used as control. The experiment was performed in a greenhouse in a randomized block scheme with three replications of 10 plants each, and the experiment was performed twice. 
Evaluations consisted on the determination of the percentage of dead plants 10 days after inoculation. Data was found not to be normally distributed and variance was not homogeneous, hence the data was analyzed with a generalized linear model, assuming a Poisson response and a logit link function, using the $\mathrm{R}$ software (R Core Team 2013) with the "multcomp" package (Hothorn et al. 2008). Contrast analysis of treatments were run by means of $z$ test (Tukey-contrasts, $\mathrm{p}<0.01$ ).

All the isolates were pathogenic and able to induce necrotic symptoms on castor stems. Additionally a high variability on the aggressiveness of the isolates was observed and this was independent from the original host of the isolate or its geographical procedence (Table 1).

Seventeen isolates were able to induce more than $75 \%$ of plant mortality and among them 10 isolates caused a mortality rate higher than $90 \%$. From the 21 isolates originally obtained from castor, 13 caused more than $75 \%$ of plant mortality and nine caused more than $90 \%$ of plant mortality. Among the six isolates originally obtained from hosts other than castor, four caused a mortality rate higher than $75 \%$, but only isolate CCMF-CNPA 278 was able to induce a mortality rate higher than $90 \%$.
A contrasting result was observed among isolates CCMF-CNPA 293 and 294, obtained from a single cotton plant: Isolate CCMF-CNPA 293 caused 80\% plant mortality whereas isolate CCMF-CNPA 294 killed only $3 \%$ of the plants.

The isolates of M. phaseolina from Bahia $(\mathrm{n}=13)$ were obtained from distinct areas where castor had been regularly grown for several years. Notwithstanding, a high variability was observed among them. Six isolates led to a mortality rate higher than $75 \%$, whereas six others led to less than $30 \%$ of plant mortality. Additionally, one isolate (CCMF-CNPA 282) caused $56.70 \%$ mortality (Table 1). A high degree of variability in aggressiveness was also found for isolates from an area where castor was being grown for the first time - Balsas/MA. A single locality which was previously utilized for the cultivation of soybean, corn and cowpea yielded four isolates, three of which (CCMFCNPA 652, 653 and 654) caused more than $75 \%$ of plant mortality, whereas one isolate (CCMF-CNPA 651) was not able to induce plant death (Table 1). Additionally to isolate CCMF-CNPA 651, only one other isolate included in this study (CCMF-CNPA 290) did not induce plant death.

The results of this study demonstrated that a high degree of variation in the aggressiveness of M. phaseolina

TABLE 1 - Pathogenicity and aggressiveness to castor (Ricinus communis) of 27 Brazilian isolates of Macrophomina phaseolina obtained from different hosts and geographical locations.

\begin{tabular}{|c|c|c|c|c|c|c|}
\hline \multirow[t]{2}{*}{ Isolate } & \multicolumn{2}{|c|}{ Original Host } & \multirow{2}{*}{$\begin{array}{l}\text { Geographical origin } \\
\text { (municipality/state) }\end{array}$} & \multirow[t]{2}{*}{ Pathogenicity $^{\mathrm{a}}$} & \multirow{2}{*}{\multicolumn{2}{|c|}{ Percent of Plant Death }} \\
\hline & Species & Cultivar & & & & \\
\hline CCMF-CNPA 287 & R. communis & CNPAM 2001-42 & Patos/PB & + & 100.00 & $\mathrm{a}^{\mathrm{c}}$ \\
\hline CCMF-CNPA 291 & R. communis & BRS Nordestina & Central/BA & + & 100.00 & $\mathrm{a}$ \\
\hline CCMF-CNPA 295 & R. communis & BRS Energia & Campina Grande/PB & + & 100.00 & $\mathrm{a}$ \\
\hline CCMF-CNPA 278 & Jatropha gossypifolia & - & Lagoa Seca/PB & + & 96.70 & $\mathrm{a}$ \\
\hline CCMF-CNPA 279 & R. communis & - & Central/BA & + & 96.70 & $\mathrm{a}$ \\
\hline CCMF-CNPA 288 & R. communis & IAC 2028 & Irecê/BA & + & 96.70 & $\mathrm{a}$ \\
\hline CCMF-CNPA 296 & R. communis & BRS Energia & Campina Grande/PB & + & 96.70 & $\mathrm{a}$ \\
\hline CCMF-CNPA 653 & R. communis & $*$ & Balsas/MA & + & 93.30 & $\mathrm{a}$ \\
\hline CCMF-CNPA 280 & R. communis & - & Central/BA & + & 90.00 & $\mathrm{a}$ \\
\hline CCMF-CNPA 292 & R. communis & BRS Nordestina & Irecê/BA & + & 90.00 & $\mathrm{a}$ \\
\hline CCMF-CNPA 669 & Arachis hypogaea & BRS 1 & Apodí/RN & + & 86.70 & $\mathrm{a}$ \\
\hline CCMF-CNPA 277 & Helianthus annuus & - & Campina Grande/PB & + & 83.30 & $a b$ \\
\hline CCMF-CNPA 283 & R. communis & BRS Energia & Irecê/BA & + & 83.30 & $a b$ \\
\hline CCMF-CNPA 293 & Gossypium hirsutum & BRS 286 & Apodí/RN & + & 80.00 & $a b$ \\
\hline CCMF-CNPA 617 & R. communis & - & Campina Grande/PB & + & 80.00 & $a b$ \\
\hline CCMF-CNPA 652 & R. communis & $*$ & Balsas/MA & + & 76.70 & $\mathrm{ab}$ \\
\hline CCMF-CNPA 654 & R. communis & $*$ & Balsas/MA & + & 76.70 & $a b$ \\
\hline CCMF-CNPA 282 & R. communis & BRS Energia & Irecê/BA & + & 56.70 & $\mathrm{~b}$ \\
\hline CCMF-CNPA 274 & Sesamum indicum & BRS Seda & Campina Grande/PB & + & 30.00 & $\mathrm{c}$ \\
\hline CCMF-CNPA 281 & R. communis & - & Central/BA & + & 26.70 & $\mathrm{c}$ \\
\hline CCMF-CNPA 285 & R. communis & BRS Energia & Irecê/BA & + & 23.30 & $\mathrm{c}$ \\
\hline CCMF-CNPA 284 & R. communis & BRS Energia & Irecê/BA & + & 16.70 & $\mathrm{~cd}$ \\
\hline CCMF-CNPA 286 & R. communis & BRS Energia & Irecê/BA & + & 6.70 & de \\
\hline CCMF-CNPA 289 & R. communis & BRS Nordestina & Irecê/BA & + & 6.70 & de \\
\hline CCMF-CNPA 294 & G. hirsutum & BRS 286 & Apodí/RN & + & 3.30 & $\mathrm{e}$ \\
\hline CCMF-CNPA 290 & R. communis & BRS Paraguaçu & Irecê/BA & + & 0.00 & $\mathrm{e}$ \\
\hline CCMF-CNPA 651 & R. communis & $*$ & Balsas/MA & + & 0.00 & $\mathrm{e}$ \\
\hline
\end{tabular}

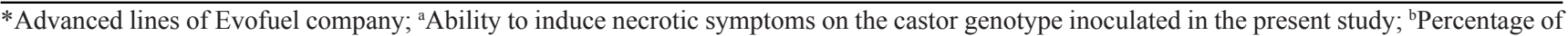
plant death as mean from both assays; ${ }^{\mathrm{c}}$ Means followed by the same letter, in the column, do not differs by $z$ test (Tukey-contrasts, $\mathrm{p}<0.01$ ). 
isolates from distinct hosts and from different geographical origins to castor exists (Table 1). This should be regarded as of major concern, particularly where castor is intended to be used as an alternative crop for rotation systems in the Brazilian Cerrado. Charcoal rot is likely to become a major problem in such situations since castor, together with soybean and corn are susceptible to this pathogen and, consequently, a progressive increase in the pathogen population is likely to occur through successive crops in areas where this scheme is adopted.

The findings for the M. phaseolina isolates included in the present study were equivalent to those of several other studies (Pearson et al. 1987; Mayek-Perez et al. 2001; Su et al. 2001; Almeida et al. 2008; Rayatpanah et al. 2012) and in agreement with their conclusions that $M$. phaseolina has no host-specificity and is highly variable for virulence or aggressiveness, even among isolates obtained from a single plant (Dhingra and Sinclair 1973).

It could also be argued that different cryptic taxa exist under the name $M$. phaseolina which might be associated with charcoal rot in Brazil. This hypothesis is strengthened by a recent work where a new species (Macrophomina pseudophaseolina) was described causing charcoal rot of Arachis hypogaea L., Hibiscus sabdariffa L. and Vigna unguiculata (L.) Walp. in Senegal (Sarr et al. 2014). According to the authors, although only isolates originated from Senegal grouped in the clade of M. pseudophaseolina, the fungus may have a much wider distribution. Additionally, the authors also highlighted that isolates used in their study could not be allocated to specific groups according to host or geographic origins. According to them, some isolates from the same host or location tended to group together, while, some isolates from the same host or location belonged to two species (e.g. M. phaseolina and M. pseudophaseolina). Therefore, it is possible that the socalled M. phaseolina, in fact includes other yet undescribed cryptic species. This might explain the variability of the results obtained in the present study and throughout the literature. Thus, further studies involving the pathogenicity and aggressiveness of Macrophomina, independently from their host species, should previously consider the possibility of elucidating the correct identity of the pathogen through molecular methods, including larger number and wider distribution of isolates as well as including the performance of cross inoculation test.

\section{ACKNOWLEDGEMENTS}

The authors would like to thanks the Conselho Nacional do Desenvolvimento Científico e Tecnológico - $\mathrm{CNPq}$ and Petrobras for research grants supporting the research on castor diseases; M.Sc. Wirton Macedo Coutinho (Embrapa Algodão) is acknowledged for his help on statistical analysis; and Dr. Liv Soares Severino (Embrapa Algodão) is thanked for his valuable comments and critical reading of the manuscript. The first author also thanks the Coordenação de Aperfeiçoamento de Pessoal de Nível Superior - CAPES for providing her with a fellowship grant.

\section{REFERENCES}

Almeida AMR, Sosa-Gomez DR, Binneck E, Marin SRR, Zucchi MI, Abdelnoor RV, Souto ER (2008) Effect of crop rotation on specialization and genetic diversity of Macrophomina phaseolina. Tropical Plant Pathology 33:257-264.

Amusa NA, Okechukwu RU, Akinfenwa B (2007) Reactions of cowpea to infection by Macrophomina phaseolina isolates from leguminous plants in Nigeria. African Journal of Agricultural Research 2:73-75.

Coutinho WM, Almeida RP, Dantas FV, Soares DJ, Araujo AE. Eficácia de misturas de fungicidas químicos na micobiota e na qualidade fisiológica de sementes de mamoneira. Campina Grande: Embrapa Algodão. 28p. (Boletim de Pesquisa e Desenvolvimento / Embrapa Algodão; n.91). Available at: http://www.infoteca.cnptia. embrapa.br/bitstream/doc/926193/1/BOLPES91.pdf. Accessed on July 03, 2014.

Dhingra OD, Sinclair JB (1973) Location of Macrophomina phaseoli on soybean plants related to culture characteristics and virulence. Phytopathology 63:934-936.

Dhingra OD, Sinclair JB (1978) Biology and pathology of Macrophomina phaseolina. Viçosa/MG, Brasil. UFV, Imprensa Universitária.

Evogene. Evogene Expands Biofuel Activity in Brazil with SLC Agricola. Available at: http://www.evogene.com/evofuel/Evogene-Expands-Biofuel-Activity-in-Brazil-with-SLCAgricola-. Accessed on July 03, 2014.

Evogene. Evogene subsidiary completes three years of successful field trials for improved castor seeds. Available at: http://www. evogene.com/evofuel/Evogene-Subsidiary-Completes-ThreeYears-of-Successful-Field-Trials-for-Improved-Castor-Seeds-. Accessed on July 03, 2014.

Grezes-Besset B, Lucante N, Kelechian V, Dargent R, Muller H (1996) Evaluation of castor bean resistance to sclerotial wilt disease caused by Macrophomina phaseolina. Plant Disease 80: 842-846.

Gupta GK, Sharma SK, Ramteke R (2012) Biology, epidemiolgy and management of the pathogenic fungus Macrophomina phaseolina (Tassi) Goid with special reference to charcoal rot of soybean (Glycine max (L.) Merrill). Journal of Phytopathology 160:167-180.

Hothorn T, Bretz F, Westfall P (2008) Simultaneous inference in general parametric models. Biometrical Journal 50:346-363.

Mayek-Perez N, Lopez-Castañeda C, Gonzalez-Chavira M, GarciaEspinosa R, Acosta-Gallegos J, La Vega OM, Simpson J (2001) Variability of Mexican isolates of Macrophomina phaseolina based on pathogenesis and AFLP genotype. Physiological and Molecular Plant Pathology 59:257-264.

Mihail JD (1992) Macrophomina. In: Singleton LL, Mihail JD, Rush CM (Eds.) Soilborne Phytopathogenic Fungi. St. Paul, USA. APS Press. pp.134-136.

Pearson CAS, Leslie JF, Schwenk FW (1987) Host preference 
correlated with chlorate resistance in Macrophomina phaseolina. Plant Disease 71:828-831.

R Core Team. R: A language and environment for statistical computing. R Foundation for Statistical Computing, Vienna, Austria. Available at: http://www.R-project.org/. Accessed on July 03, 2014.

Reis EM, Boaretto C, Danelli ALD. (2014). Macrophomina phaseolina: density and logevity of microsclerotia in soybean root tissues and free on the soil, and competitive saprophytic ability. Summa Phytopathologica 40:128-133.

Rayatpanah S, Nanagulyan SG, Alav SV, Razavi M, GhanbariMalidarreh A (2012) Pathogenic and genetic diversity among Iranian isolates of Macrophomina phaseolina. Chilean Journal of
Agricultural Research 72:40-44.

Sarr MP, Ndiaye M, Groenewald JZ, Crous P. (2014) Genetic diversity in Macrophomina phaseolina, the causal agent of charcoal rot. Phytopathologia Mediterranea 53: 250-268.

Severino LS, Auld DL, Baldanzi M, Candido MJD, Chen G, Crosby W, Tan D, He X, Lakshmamma P, Lavanya C, Machado OLT, Mielke T, Milani M, Miller TD, Morris JB, Morse SA, Navas AA, Soares DJ, Sofiatti V, Wang ML, Zanotto MD, Zieler $\mathrm{H}$ (2012) A review on the challenges for increased production of castor. Agronomy Journal 104:853-880.

Su G, Suh SO, Schneider RW, Russin JS (2001) Host specialization in the charcoal rot fungus, Macrophomina phaseolina. Phytopathology 91:120-126. 